\title{
Kinematic and Dynamic Analysis and Distribution of Stress in Items of Planar Mechanisms by Means of the MSC ADAMS Software
}

Ján Vavro jr., Ján Vavro, Petra Kováčiková, Radka Bezdedová, Jakub Híreš

Faculty of Industrial Technologies in Púchov, Alexander Dubček University of Trenčín. I. Krásku 491/30, 02001 Púchov. Slovac Republic. E-mail: jan.vavro.jr@fpt.tnuni.sk, jan.vavro@fpt.tnuni.sk, petra.kovacikova@fpt.tnuni.sk, radka.bezdedova@fpt.tnuni.sk,jakub.hires@fpt.tnuni.sk

This paper presents a kinematic and dynamic analysis and distribution of the stress in items of a planar mechanism by means of the MSC ADAMS software. Graphic dependence of kinematic and dynamic magnitudes of some points is given in dependence on the angle of rotation of the driving item and in dependence on the time. Distribution of the stress in the items presented is in [Pa]. In relation to the kinematic and dynamic analysis and subsequent simulation [1-3] of the planar as well as spatial mechanisms, it is great solution to use MSC Adams software program. The considerable advantage of this mentioned program is based on its simplicity from the aspect of modelling and moreover, it is important to point out that utilisation of the mentioned program leads to results which are precise and accurate in the case of the numerical solution of the equations in the whole magnitude referring to motion of mechanism while the given results are obtained in the graphic form.

Keywords: kinematic analysis, dynamic analysis, finite element method, planar mechanism

\section{Acknowledgement}

This work was supported by the Slovak Grant Agency VEGA 1/0649/17, KEGA 007TnUAD-4/2017, and resulted from the project "Center for quality testing and diagnostics of materials", ITMS code 26210120046 relating to the Operational Program Research and Development funded from European Fund of Regional Development.

\section{References}

[1] PAUL, B. (1979) Kinematics and Dynamics of Planar Machinery, Prentice-Hall, New Jersey, 1979.

[2] BRÁT, V. (1976). Handbook of kinematics with examples, SNTL, Prague, 1976. (in Czech)

[3] SAPIETOVÁ, A., SAGA, M., HYBEN, B., SAPIETA, M. (2014). Effective methods of parameters refinement of machinery in the program MSC ADAMS, Applied Mechanics and Materials 611 (2014) 67-74.

[4] SAPIETOVÁ, A., SAPIETA, M., HYBEN, B. (2013). Document Sensitivity analysis application for multibody system synthesis, Applied Mechanics and Materials 420 (2013) 68-73.

[5] SAPIETOVÁ, A., SÁGA, M., SHIMANOVSKY, A., SAPIETA, M. (2014). Mobility of multibody systems in terms of their incorrectness, Communications 16(3A), (2014) 6-12.

[6] SAPIETOVÁ, A., DEKÝŠ, V., VAŠKO, M. (2010). A numerical model of rotating machine having unbalance and the measurements of its dynamical properties, Metalurgija (Metalurgy) 49 (2010) 503-507.

[7] SÁGA. M., VAŠKO, M., KOPAS, P., JAKUBOVIČOVÁ, L. (2014). Numerical algorithm for beam residual stress identification, Communications 16(3A), (2014) 13-18.

[8] KLIMENDA, F., JSOUKUP, J., ZMINDAK, M. (2016). Deformation of Aluminium Thin Plate, Manufacturing Technology, Volume 16, (2016), ISSN 1213-2489, 124-129.

[9] STANKOVIČOVÁ, Z., DEKÝŠ, V., NOVÁK, P., SAPIETA, M. (2015). Numerical Simulation of Thermoelastic Stress Analysis, Manufacturing Technology, Volume 15, (2015), ISSN 1213-2489, 925-930.

[10] HANDRIK, M., SÁGA, M., PECHÁČ, P., KOPAS, P. (2015). Analysis of Force Conditions of the Hot Forming Machine in Rolling-Out of Bearing Rings, Manufacturing Technology, Volume 15, (2015), ISSN 1213-2489, 821825 .

[11] ŽMINDÁK, M., MEŠKO, J., PELAGIĆ, Z., ZRAK, A. (2014). Finite Element Analysis of Crack Growth in Pipelines, Manufacturing Technology, Volume 14, (2014), ISSN 1213-2489, 116-122.

[12] DELYOVÁ, I., HRONCOVÁ, D., FRANKOVSKÝ, P. (2014). Analysis of Simple Mechanism Using MSC Adams, Manufacturing Technology, Volume 14, (2014), ISSN 1213-2489, 141-145. 